\title{
EFFECT OF REUSE BIOFLOC WATER ON GROWTH PERFORMANCE, FEED UTILIZATION OF NILE TILAPIA FINGERLINGS (OREOCHROMIS NILOTICUS)
}

\author{
Eid A.E., Khloud G. Showhdy, Mervat A. M. Ali and Amal Elfeky
}

Dept. of Animal and Fish Resources- Faculty of Agriculture- Suez Canal University, Ismailia 41522, Egypt.

\author{
(Received 12/4/2021, accepted 9/6/2021)
}

\section{SUMMARY}

$\mathrm{N}$

ile tilapia(Oreochromis niloticus) fingerlings (average weight and length: $20.20 \pm 0.20 \mathrm{~g}, 10 \pm 0.25 \mathrm{~cm}$ ) cultivated at reusing water from systems with biofloc technology (BFT) under three treatments: T1: Control, T2: tilapia cultured in reused water biofloc (RW) with adding carbohydrate and T3: tilapia cultured in reused water biofloc (RW) without adding carbohydrate. Nine rectangular tanks $(66$ × 47 x $44 \mathrm{~cm}$, 75L) were used with stocking densities (400 Fish/m3) for 60 days to investigate fish growth performance, feed utilization, body composition, survival, water quality and also economic evaluation was done. Fish were fed a commercial diet containing $30 \%$ crude protein. Growth performance of tilapia was recorded biweekly. Water temperature, dissolved oxygen and $\mathrm{pH}$, were recorded daily, while $\mathrm{NO}_{2}-$, NO3-N; total hardness, carbonate hardness and total suspended solids were recorded biweekly. The body composition of the whole fish was determined at the end of the experiment. Results showed that the best water quality parameters, finial body weight, weight gain, daily weight gain, specific growth rate, final biomass, net yield, PER, FCR, FE, feed intake and economic evaluation were significantly $(\mathrm{P}<0.05)$ higher in $\mathrm{T} 2$ andT3 than $\mathrm{T} 1$. Survival rate was greater than $98 \%$ in all treatments, with no significant difference between them $(\mathrm{P}>0.05)$. The present study recommended rearing Nile tilapia in reusing water from systems with biofloc technology (BFT) without adding carbon source for best growth performance and prolonged the useful life, quality of water and reduced overall water consumption.

Keywords: Biofloc, Nile tilapia, feed utilization, growth performance and body composition.

\section{INTRODUCTION}

Nile tilapia is an economically important species. It is the second cultured species in the world, contributing significantly to global food security (Dawood et al., 2019; Van Doan et al., 2019; Amin et al., 2019 and Magouz et al., 2020). Nile tilapia is a tropical fish species that can be reared efficiently in warm water with temperature ranged from 25 to $30^{\circ} \mathrm{C}$ (Dawood et al., 2020).

It is necessary to prolong the useful life of freshwater to guarantee aquaculture production (FAO, 2018) by using cultivation techniques that have an advantage over traditional fish farming practices; for example, using biofloc technology (BFT) (Avnimelech, 2009), It is important to add Carbohydrate for improving $\mathrm{C}: \mathrm{N}$ ratios because in most artificial feeds the $\mathrm{C}: \mathrm{N}$ ratio cannot meet the needs of heterotrophic bacteria (Avnimelech, 2012).

Biofloc technology is considered as the new blue revolution in Aquaculture, because it exploits the proliferation of microorganisms (bacteria, fungi, microalgae and zooplankton) using carbon source to maintain water quality.

BFT systems have resulted in advances in the production of tilapia with regard to the different growth stages (Caipang et al., 2015 and García-Ríos et al., 2019). It has a positive effect on the proximal composition of the cultured organisms and the nutrition of brood stock, 


\section{Eid et al.}

due to the consumption of the microorganisms present in the biofloc (Ekasari et al., 2013 and Pérez-Fuentes et al., 2018).

Nile tilapia can be cultured in biofloc using up to $100 \%$ reuse water derived from other BFT systems because it can tolerate adverse environmental conditions and is considered to be one of the most physiologically adaptable species to biofloc culture, which allows cultivation at high densities (Pérez-Fuentes et al., 2016). The reduction in water consumption using BFT could be greater if the same water can be reused in multiple culture cycles (Krummenauer et al .2014).

The objective of the present study was to evaluate the effect of the reuse of biofloc water and the effects of no carbohydrate addition for Nile Tilapia production on growth performance, feed utilization, body composition, water quality and economical Evaluation.

\section{MATERIALS AND METHODS}

\section{Study site:}

The experiment was performed at the experimental fish lab, Department of Animal and Fish Resources, Faculty of Agriculture, Suez Canal University, Egypt. The experiment established for 60 days from 28 August to 25 October 2020.

\section{Experimental Fish:}

Nile tilapia fingerlings obtained from a private fish hatchery (Khalil Saad Khalil Hatchery), Ismailia, with average body weight $20.35 \pm 0.35 \mathrm{~g}$ and body length $10 \pm 0.25 \mathrm{~cm}$ were acclimatize for 7 days prior the start of the experiment. Fish were fed on the same diet used in the study. Prior the experiment fish were starved for $24 \mathrm{~h}$ and measuring there total length and body weight.

\section{Experimental tanks:}

Experiment was carried out in 9 rectangular tanks $(66 \times 47 \times 44 \mathrm{~cm})$ of reinforced plastic with water volume $75 \mathrm{~L}$, tanks were supplied with dechlorinated tap water. Aeration was continuously provided using an air blower in the tanks. In control treatments (clear system) water was exchanged daily to remove feaces and uneaten feed, while for experimental BFT tanks, no water exchange was done (zero water exchange); with the exception of compensation for the evaporated portion. During the experimental period fish were held under natural light system (12:12 h, light: dark).

\section{Experimental design:}

\begin{tabular}{cc}
\hline No of the treatment & Treatment \\
\hline 1 & Clear system (control) \\
2 & Water-reusing biofloc with carbohydrate addition \\
3 & Water-reusing biofloc with no carbohydrate addition \\
\hline
\end{tabular}

All tanks were stocked with Nile tilapia fingerlings at stocking densities (400 Fish/m3). In this study sugar was used as an external carbon source it was added in three tanks, while in the other three tanks no carbohydrate was added. Suger was added after two hours of feeding at the same amount of feeding ration to maintain the optimal $\mathrm{C}$ : $\mathrm{N}$ ratio for activate heterotrophic bacteria growth (>N15:1) (Avnimelech, 1999). Adding carbohydrate, aeration conditions are the main circumstances that cause floc growth and develop (Azim and Little, 2008).

Water-contained flocs were reused from tanks already rich in flocs before the start of experiment for one month. The initial physicochemical concentrations of water were TSS $(650.55 \mathrm{mg} / \mathrm{l})$, TAN $(3.6 \mathrm{mg} / \mathrm{l})$ and $\mathrm{NO}_{3}-\mathrm{N}(450.8 \mathrm{mg} / \mathrm{L})$. 


\section{Experimental Diets:}

Fish in all treatments were fed commercial diet containing (30\% crude protein) at daily feeding rate $3 \%$ of the total stocked biomass divided into two equal portions offered two times/day (9.00 and 14.00). Feed were re-adjusted bi-weekly after weighing fish. Proximate chemical analysis of the experimental diet showed in Table (1).

Table (1): Chemical composition of the diets.

\begin{tabular}{lc}
\hline Component & Content $(\%$ on DM $)$ \\
\hline Dry mater & 90.1 \\
Crude Protein & 30.3 \\
Fat & 6.1 \\
Ash & 4.95 \\
Crude fiber & 4.8 \\
NFE $^{1}$ & 53.85 \\
Organic carbon & 37.45 \\
GE $(\text { Kcal } / 100 \mathrm{~g})^{2}$ & 450.70 \\
\hline
\end{tabular}

Nitrogen Free Extract $=100-($ protein + fat + ash + fiber $) G E=$ gross energy was calculated as 5.65 ,

9.45 and $4.12 \mathrm{Kcal} / 100 \mathrm{gram}$ of protein, lipid and carbohydrate, respectively after (NRS, 2011)

\section{Water quality:}

Water temperature and dissolved oxygen were measured using a portable oxygen meter (OxyGuard meter) daily at $13.00 \mathrm{~h}$. $\mathrm{pH}$ values were recorded daily using a portable $\mathrm{pH}$ meter (OxyGuard meter).

Water sample $(50 \mathrm{ml})$ were collected from each tank and filtered by filter papers for analyzed (TAN), (TSS), Nitrite-N (NO2-N) and Nitrate-N (NO3-N). Ammonia nitrogen (TAN). Nitrite and nitrate was measured bi-weekly using spectrophotometer. Total suspended solid (TSS) values were measured twice during the experimental using Spectrophotometer (LKB Bichrom UV visible spectrophotometer) according to (APHA, 1992; Mullin and Riley, 1955).

\section{Biofloc volume:}

Biofloc volume (water settle able solids) was determined weekly using Imhoff cone to monitor the developing of biofloc, Imhoff or settling cones are a simple way to index suspended solids concentration. The cones have marked graduations on the outside that used to mensuration the volume of solids that settle from 1 liter of system water. Registering the volume of biofloc at $1000 \mathrm{~mL}$ of the tank water after 15-20min sedimentation according to (Avnimelech \& Kochba, 2009).

\section{Growth Performance and Feed utilization:}

The growth achievement parameters and feed along with protein utilization variables were calculated with the following equations:

Average weight gain $(\mathrm{AWG})=$ Average final weight $(\mathrm{g})-$ Average initial weight $(\mathrm{g})$.

Average daily gain $(\mathrm{ADG})=[$ Average final weight $(\mathrm{g})-$ Average initial weight $(\mathrm{g})] /$ time by days.

Specific growth rate $($ SGR \%/day $)=100[(\mathrm{LnWt} 1-\mathrm{Ln} \mathrm{Wt} 0) / \mathrm{t}]$.

Where: Ln: normal log, Wt0: initial weight $(\mathrm{g})$, Wt1: final weight $(\mathrm{g}), \mathrm{T}$ : time by days.

Survival $(\%):($ Final number of fish/Initial number of fish) $\times 100$.

Net yield $(\mathrm{g})=$ Final biomass $(\mathrm{g}) /$ tank - Initial biomass $(\mathrm{g} / \mathrm{tank})$.

Feed conversion ratio $(\mathrm{FCR})=$ Feed intake $(\mathrm{g}) / \mathrm{WG}(\mathrm{g})$.

Feed conversion efficiency $(\mathrm{FCE})=\mathrm{WG}(\mathrm{g}) /$ Feed intake $(\mathrm{g})$.

Protein efficiency ratio $(\mathrm{PER})=\mathrm{WG}(\mathrm{g}) /$ protein intake $(\mathrm{g})$. 


\section{Eid et al.}

\section{Chemical analysis of fish and biofloc:}

At the end of experiment a random sample of fish was sampled from each tank at different treatments and precipitated flocs were collected from different treatments for determination of proximate composition. Chemical analysis of biofloc and whole-body DM\%, CP\%, EE \% and ash content \% were performed according to standard (AOAC, 1995) methods. Fish and biofloc sample were dried in an oven at $70^{\circ} \mathrm{C}$ for a period of 24 hours till constant weight, then grounded and stored at $-20^{\circ} \mathrm{C}$ for analysis, ash content was determined by incineration at $600^{\circ} \mathrm{C}$ for $2 \mathrm{~h}$, Crude protein was determined by micro-Kjeldhal method, $\% \mathrm{~N} \times 6.25$ (using Kjeltech auto analyzer, Model 1030, Tecator, Höganäs, Sweden). Fat content was determined by Soxhelt extraction with petroleum ether $\left(40-60^{\circ} \mathrm{C}\right)$.

\section{Statistical analysis:}

The data were analyzed by one-way ANOVA using Statistical Analysis System SAS version 9.0.0 (SAS, 2004) program at $\mathrm{P}<0.05$ level, means were compared by Duncan new multiple range test (Duncan, 1955).

\section{Economical evaluation:}

The cost of feed to raise unit biomass of fish was estimated by a simple economic analysis. The estimation was based on local retail sale market price of all the dietary ingredients at the time of the study.

Cost $/ \mathrm{kg}$ diet $(\mathrm{LE})=$ Cost per $\mathrm{Kg}$ diet L.E.

Consumed feed to produce $1 \mathrm{~kg}$ fish $(\mathrm{kg})=$ Feed intake per fish per period/ final weight per fish $\mathrm{Kg} / \mathrm{Kg}$

Feed cost per $\mathrm{kg}$ fresh fish $(\mathrm{LE})=$ amount of feed $\mathrm{X}$ price

Relative $\%$ of feed cost $/ \mathrm{kg}$ fish $=$ Respective figures for step 3/ highest figure in this step .

Feed cost $/ 1 \mathrm{Kg}$ gain $(\mathrm{LE})=$ Feed intake per $\mathrm{Kg}$ gain $\mathrm{X}$ Cost $/ \mathrm{kg}$ diet $(\mathrm{LE})$

Relative $\%$ of feed cost of $\mathrm{Kg}$ gain $=$ Respective figures for step 5/ highe st figure in this step

* Cost of $1 \mathrm{~kg}$ diet used was 7.20 L.E.

\section{RESULTS AND DISCUSSION}

\section{Water quality:}

The results of the physical and chemical variables of the water are shown in Table (2). Water temperature ranged from $\left(27.5-27.60{ }^{\circ} \mathrm{C}\right), \mathrm{pH}$ value were $(8.03,7.50$ and 7.10$)$, Dissolved Oxygen (DO) was $(6.58,6.40$ and $6.51 \mathrm{mg} / \mathrm{l})$ for treatments (T1, T2 and T3), respectively, throughout the experimental period, and were within the acceptable level for Nile tilapia in all treatments (Kubitza, 2011). There were no significant differences between temperature and DO in all treatments. However, the control treatment had higher concentrations of DO than the rest of other treatments with a carbon source. This is may possibly due to the absence of bacterial biomass, which is present in the tanks with biofloc, in addition to greater photosynthetic activity. Avnimelech (2011) suggests that the minimum concentration of dissolved oxygen for the farming of tilapia in bioflocs should be $4 \mathrm{mg} / \mathrm{l}$.

$\mathrm{pH}$ In the control treatment, $\mathrm{pH}$ value was significantly higher than other treatments $(\mathrm{P} \leq 0.05)$ it could be attributed to response to adding carbon source and accumulation of nitrifying bacteria in the system, which was clearly observed in treatments (T2 and T3) this was in agreement with (Pérez-Fuentes et al., 2016) .

Total alkalinity was $(48.89,70.00$ and $56.11 \mathrm{mg} \mathrm{L} / 1 \mathrm{CaCO} 3)$ for $\mathrm{T} 1, \mathrm{~T} 2$ and $\mathrm{T} 3$, respectively. There were a significant $(\mathrm{P}<0.05)$ differences between all treatments. This was in agreement with (Azim and Little, 2008), who reported that a biofloc system reduces the buffering capacity of the water, requiring the constant addition of correctives.

The total ammonia nitrogen (TAN) values were $2.20,3.70$ and $3.16 \mathrm{mg} / 1$ for $\mathrm{T} 1, \mathrm{~T} 2$, and $\mathrm{T} 3$ 
treatments, respectively. The lowest concentration for TAN was obtained in T1 treatment, which differed significantly from $\mathrm{T} 2$ and $\mathrm{T} 3(\mathrm{P} \leq 0.05)$, because ammonia conversion rate was slower in control due to the absence of heterotrophic bacteria than BFT treatments but did not differ fromT1 $(\mathrm{P}>0.05)$.

Table (2): Water quality parameters for experimental groups which reared on three water systems.

\begin{tabular}{lccc}
\hline Parameter & T1 (Control) & T2 $(\mathrm{Bf}+\mathrm{c})$ & T3 $(\mathrm{Bf}-\mathrm{c})$ \\
\hline Temperature $\left({ }^{\circ} \mathrm{C}\right)$ & $27.54 \pm 1.20$ & $27.54 \pm 1.20$ & $27.68 \pm 0.58$ \\
pH & $8.03 \pm 0.01 \mathrm{a}$ & $7.50 \pm 0.01 \mathrm{~b}$ & $7.10 \pm 0.01 \mathrm{~b}$ \\
$\mathrm{DO}(\mathrm{mgL}-1)$ & $6.58 \pm 0.09$ & $6.40 \pm 0.09$ & $6.51 \pm 0.09$ \\
$\mathrm{CO}_{2}(\mathrm{mgL}-1)$ & $4.50 \pm 0.75$ & $4.50 \pm 0.75$ & $4.50 \pm 0.75$ \\
$\mathrm{Alkalinity}(\mathrm{mgL}-1)$ & $48.89 \pm 0.82 \mathrm{c}$ & $70.00 \pm 0.84 \mathrm{a}$ & $56.11 \pm 0.84 \mathrm{~b}$ \\
Ammonia $(\mathrm{mgL}-1)$ & $0.34 \pm 0.04$ & $0.35 \pm 0.08$ & $0.34 \pm 0.09$ \\
Floc level (mlL-1) & $<0.5$ & $20.61 \pm 0.80$ & $20.17 \pm 1.35$ \\
$\mathrm{TAN}(\mathrm{mg} / \mathrm{L})$ & $2.20 \pm 0.84 \mathrm{~b}$ & $3.70 \pm 0.24 \mathrm{a}$ & $3.56 \pm 0.24 \mathrm{a}$ \\
$\mathrm{NO}_{2}-\mathrm{N}-(\mathrm{mg} / \mathrm{L})$ & $0.80 \pm 0.84 \mathrm{~b}$ & $0.99 \pm 0.55 \mathrm{a}$ & $0.56 \pm 0.54 \mathrm{c}$ \\
$\mathrm{NO}_{3}-\mathrm{N}-(\mathrm{mg} / \mathrm{L})$ & $450.30 \pm 1.10 \mathrm{~b}$ & $321.18 \pm 88.9 \mathrm{c}$ & $466.82 \pm 177.3 \mathrm{a}$ \\
$\mathrm{SRP}(\mathrm{mg} / \mathrm{L})$ & $22.20 \pm 1.10 \mathrm{~b}$ & $19.36 \pm 6.19 \mathrm{c}$ & $42.20 \pm 11.15 \mathrm{a}$ \\
$\mathrm{TSS}(\mathrm{mg} / \mathrm{L})$ & $588.64 \pm 441 \mathrm{c}$ & $841.51 \pm 441 \mathrm{a}$ & $634.99 \pm 277.3 \mathrm{~b}$ \\
$\mathrm{SVI}-15(\mathrm{ml} / \mathrm{g})$ & $18.2 \pm 10.5 \mathrm{c}$ & $100.51 \pm 88.2 \mathrm{a}$ & $26.2 \pm 18.2 \mathrm{~b}$ \\
\hline
\end{tabular}

Data are presented as means \pm standard error (SE). Values in the same row with different superscript letters are significantly different $(P<0.05)$.

$\mathrm{NO}_{2}$ showed mean values of $(0.80,0.99$ and $0.56 \mathrm{mg} / \mathrm{l})$ and $\mathrm{NO}_{3}$ were $(450.30,321.18$, $466.82 \mathrm{mg} / \mathrm{l}$ ) for $\mathrm{T} 1, \mathrm{~T} 2$ and T3 treatments, respectively, with a statistical difference between treatments $(\mathrm{P}<0.05)$, these are in agreement with (Yanbo et al., 2006). Nitrite and nitrate were accumulated during the first weeks due to the processes of nitrification in biofloc systems, while, control treatment was renewed daily, which prevented the nitrate from accumulating NO2-N concentration in BFT and seems to be relatively stable. The opposite was observed in control treatments, which might be explained by the higher rate of nitrification processes in these treatments, this was in agreement with Azim and Little, (2008).

Table (2) showed that TSS were $(588.64,841.51$ and $634.99 \mathrm{mg} / \mathrm{l})$ for treatments (T1, T2 and T3), respectively. Control treatment recorded the lowest concentration and $\mathrm{T} 2$ recorded the highest one followed by T3. There were significant differences between all treatments $(\mathrm{P}<0.05)$. SRP were $(22.20,19.36$ and $42.20 \mathrm{mg} / \mathrm{l})$ for treatments $(\mathrm{T} 1, \mathrm{~T} 2$ and $\mathrm{T} 3)$, respectively. In T2 (biofloc $+\mathrm{C}$-tanks $19.36 \mathrm{mg} / \mathrm{L}$ ) was decreased recording the lowest concentration, while it was consistently accumulated in $\mathrm{T} 3(42.20 \mathrm{mg} / \mathrm{l})$ and recorded the highest concentration; there were significant differences between all treatments $(\mathrm{P}<0.05)$.

The higher level of TSS and lower concentrations of SRP indicated organic carbon addition stimulates the growth of heterotrophic bacteria, the TAN was assimilated and converted into microbial biomass; as a consequence, the TSS levels can increase this was in agreement with (Long et al., 2015 and Nootong, 2011).

Phosphorus in feed is largely $(80 \%-90 \%)$ released into aquaculture systems, it is a necessary nutrient element for bacteria growth, cannot be converted into gas and removed like nitrogen. Its conversion into the microbe's biomass is the most common biological phosphorus removal method (Barak et al., 2003). In the current study, SRP in T2 (biofloc + C -tanks $19.36 \pm 6.19 \mathrm{mg} / \mathrm{L}$ ) was decreased, while it was consistently accumulated in $\mathrm{T} 3$ tanks. In carbohydrate-added tanks (T2), as the microbe's biomass (flocs) was growth higher than that of T3 tanks, the TSS level was higher $841.51 \pm 441 \mathrm{mg} / \mathrm{L}$ than that of T3 tanks $(634.99 \pm 277.3)$, more SRP may be stored in the flocs and removed during the management when flocs were taken out.

The higher accumulation of NO3-N and lower level of NO2-N in the T3 tanks indicated that nitrification is enhanced when no carbohydrate is added in BFT aquaculture systems. 


\section{Eid et al.}

According to the removal of nitrogen in aquaculture, nitrogen in excretion, faeces and unutilized feed is or firstly converted into the form of TAN (Crab et al., 2007). As the same amount of nitrogen (the same amount of feed) was provided to all tanks and heterotrophic bacteria was enhanced in T2 (TSS increased faster than T3), more TAN may have been assimilated by heterotrophic bacteria than that of T3. While the concentrations of TAN in all tanks had no differences. It indicated that more TAN may be converted by nitrification or assimilated by nitrifying bacteria inT3 (biofloc $-\mathrm{C}$-tanks) than T2 (biofloc $+\mathrm{C}$-tanks). TAN had low concentrations in all groups, this was in agreement with (Azim \& Little, 2008; Xu et al., 2016a and $\mathrm{Xu}$ et al., 2016b) who demonstrated that it can be controlled by both assimilation and nitrification.

Low levels of TSS and SVI in T3 tanks help to maintain DO concentrations and remove excess flocs. Some studies suggested TSS concentration in BFT aquaculture systems should be controlled not too high (Avnimelech, 2012).

\section{Nutritional quality of flocs:}

Table (3) showed that protein contents of flocs in T2 $(26.20 \pm 0.62 \%)$ were significantly higher than that in T3 $(24.30 \pm 0.47 \%)$. The crude lipid contents of flocs in T2 were similar with that in T3. More nitrogen was assimilated and converted into the form of bacteria when C: $\mathrm{N}$ ratios increased. Significantly higher protein content in flocs was achieved in this experiment and $\ddot{b}$ in previous studies (Azim \& Little, 2008 and Nootong \& Pavasant, 2011).

Table (3): Nutritional compositions (\% dry basis) of flocs in T1 control, T2 carbohydrate -added tanks (biofloc $+c$-tanks) and T3 no carbohydrate-added tanks (biofloc C-tanks)

\begin{tabular}{lccc}
\hline Composition of flocs & T1 & T2 & T3 \\
\hline Protein & $12.60 \pm 0.20 \mathrm{c}$ & $26.20 \pm 0.62 \mathrm{a}$ & $24.30 \pm 0.47 \mathrm{~b}$ \\
Crude lipid & $2.80 \pm 0.40 \mathrm{~b}$ & $7.40 \pm 0.40 \mathrm{a}$ & $6.80 \pm 0.42 \mathrm{a}$ \\
\hline
\end{tabular}

Data are presented as means \pm standard error (SE). Values in the same row with different superscript letters are significantly different $(p<0.05)$.

In this study crude protein varied from 24.30 to $26.20 \%$ and was slightly lower than that suggested by( Azim and Little, 2008), however these values are higher than those found (23.7$25.4 \%$ ) by (Elías et al., 2015). This may be due different fish species, environmental conditions or experimental error.

\section{Growth performance and yield parameters:}

Different growth parameters of Nile tilapia (O. niloticus) fingerlings of the experimental groups were shown in Table (4). The initial body weight was approximately $(20.05 \mathrm{~g})$ with no significant difference among experimental groups. The finial body weight, weight gain, daily weight gain, specific growth rate, initial biomass, final biomass and net yield were significantly $(\mathrm{P}<0.05)$ highest in $\mathrm{T} 2$ andT3. No significant different $(\mathrm{P}<0.05)$ between the group of fingerlings Nile tilapia on (T2, tanks) and (T3, tanks). By adding carbon source to the culture medium in limited-discharge systems (i.e., by changing the $\mathrm{C}$ : $\mathrm{N}$ ratio), it is possible to obtain a significant enhancement of bacterial growth and of the fixation of toxic nitrogen metabolite species (Hari et al., 2006; Avnimelech, 2009 and Crab, 2010). In addition to the improvement in water quality, the increase in bacterial biomass, which provides supplemental feed, is known to be associated with improved fish survival and growth and to reduce the releases of nutrient-rich water into receiving streams (De Schryver et al., 2008; Avnimelech 2009 and Krummenauer et al., 2011).

The average daily weight gain of Nile tilapia was $(0.25-0.32 \mathrm{~g} /$ day $)$, which suggest that the growth of tilapia during their culture in biofloc with reuse water was not affected by the quality of the water from the BFT culture. Therefore, the useful life of the water can be prolonged at least for the development of a new biofloc culture cycle. This is consistent with reports from other researchers, who indicated that the use of the same water from prior BFT cultures is highly beneficial for the culture of L. vannamei shrimp, because good water quality is maintained, and the productive performance is increased. (Krummenauer et al., 2014). 
After 60 days of culture, the total production of tilapia in $\mathrm{T} 2$ was $(752 \pm 1.2 \mathrm{~g} / \mathrm{tank})$ which indicates that the cultivation of tilapia in biofloc with reuse water affect the productive performance in agreement with (Azim and Little, 2008 and Eid et al., 2020).

Survival rate was greater than $95 \%$ in all treatments, with no significant difference between them $(\mathrm{P}>0.05)$. This suggests that reuse water derived from BFT cultures can be used in the development of a new biofloc culture and does not negatively impact the survival of tilapia. The survival rate recorded in the present study is comparable to the survival rate reported by other researchers for tilapia (93 to 95 percent) when cultivated in biofloc from first-use water or reused water (Luo et al., 2014 and Eid et al., 2020).

Some other studies reported that the addition of carbohydrate sources in the BF system may improving the growth performance and feed utilization, which depends on the use of different $\mathrm{C}$ : $\mathrm{N}$ ratios and different feed intake levels as well as the differences in the carbon sources (Wang et al., 2015 and Zhao et al.,2016) .

Table (5): Growth performance of fingerlings Nile tilapia reared on biofloc water and reused biofloc without adding sugar.

\begin{tabular}{lccc}
\hline Parameter & Control & $\mathrm{T} 2$ & $\mathrm{~T}$ \\
\hline Initial weight $(\mathrm{g})$ & $20.05 \pm 0.20$ & $20.2 \pm 0.20$ & $20.15 \pm 0.20$ \\
Final weight(g) & $34.830 .20 \mathrm{~b}$ & $39.6 \pm 0.40 \mathrm{a}$ & $38.12 \pm 0.60 \mathrm{a}$ \\
Weight gaing $\mathrm{g}$ & $14.7 \pm 8 \pm 0.44 \mathrm{~b}$ & $19.4 \pm 0.64 \mathrm{a}$ & $17.97 \pm 0.54 \mathrm{a}$ \\
Weight gain/day & $0.25 \pm 1.04 \mathrm{~b}$ & $0.32 \pm 1.04 \mathrm{a}$ & $0.30 \pm 1.04 \mathrm{a}$ \\
SGR & $0.92 \pm 1.04 \mathrm{~b}$ & $1.13 \pm 1.04 \mathrm{a}$ & $1.06 \pm 1.04 \mathrm{a}$ \\
Initial number (fish/tank) & 20 & 20 & 20 \\
Initial biomass $(\mathrm{g} / \mathrm{tank})$ & $401.00 \pm 0.04$ & $404.00 \pm 0.20$ & $403.00 \pm 0.24$ \\
Final biomass g/tank & $661 \pm 1.44 \mathrm{~b}$ & $752 \pm 1.24 \mathrm{a}$ & $724 . \pm 1.54 \mathrm{a}$ \\
Net Yield g & $260.27 \pm 22.24 \mathrm{~b}$ & $348.4 \pm 22.20 \mathrm{a}$ & $321.3 \pm 32.30 \mathrm{a}$ \\
Survival rate & $95.00 \pm 1.04$ & $95.00 \pm 1.04$ & $95.00 \pm 1.04$ \\
\hline
\end{tabular}

Data are presented as means \pm standard error $(S E)$.Values in the same row with different superscript letters are significantly different $(P<0.05)$.

\section{Feed Utilization:}

Feed utilization data for fingerlings Nile tilapia were presented in Table 5. There were significant differences $(\mathrm{P}<0.05)$ between all experimental groups. There were no significant $(\mathrm{P}<0.05)$ differences among experimental groups ( $\mathrm{T} 2$ and $\mathrm{T} 3) . \mathrm{T} 2$ and $\mathrm{T} 3$ had the best feed utilization parameters than the control group.

Table (5): Feed utilization for fingerlings Nile tilapia reared under three water systems.

\begin{tabular}{lccc}
\hline Item & T1 (CO.) & T2 $(\mathrm{Bf}+\mathrm{c})$ & T3 $(\mathrm{Bf}-\mathrm{c})$ \\
\hline Feed intake & $33.41 \pm 1.20 \mathrm{a}$ & $31.13 \pm 1.20 \mathrm{~b}$ & $31.13 \pm 1.40 \mathrm{~b}$ \\
FCR & $2.27 \pm 0.20 \mathrm{a}$ & $1.61 \pm 0.20 \mathrm{~b}$ & $1.73 \pm 0.20 \mathrm{~b}$ \\
FE & $0.44 \pm 0.20 \mathrm{~b}$ & $0.62 \pm 0.20 \mathrm{a}$ & $0.58 \pm 0.40 \mathrm{a}$ \\
PER & $1.47 \pm 0.20 \mathrm{~b}$ & $2.06 \pm 0.20 \mathrm{a}$ & $1.92 \pm 0.60 \mathrm{a}$ \\
\hline
\end{tabular}

Data presented as means \pm standard error (SE).Values in the same row with different superscript letters are significantly different $(p<0.05)$.

The results of the present study indicated that fish in T2 and T3 had better growth and feeding performance than T1. Weight gain, SGR, and PER were at the highest levels and FCR at the lowest level in fish with $\mathrm{C} / \mathrm{N}$ ratio of 15:1. In some studies, the positive effects of the application of BFT on growth performance and FCR have been reported in different species, e.g., in O. niloticus (Mirzakhani et al., 2019 and Eid et al., 2020), L. vannamei (Khanjani et al., 2017 and Panigrahi et al., 2019), L. rohita (Ahmad et al., 2016), C. auratus (Wang et al., 2015), and C. carpio (Najdegerami et al., 2016). However, (Bakhshi et al., 2018) stated that no 


\section{Eid et al.}

significant difference was observed between the control and BFT treatments with different carbon sources in terms of the final weight, final productivity, weight gain, and SGR of common carp fingerlings, although a small increase was noticed.(Dauda et al. 2018) mentioned that the biomass gain, SGR, and FCR of C. gariepinus were not significantly different among the control and BFT treatments with different $\mathrm{C} / \mathrm{N}$ ratios probably because this species is an inefficient filter feeder of bioflocs (Ekasari et al., 2016).

\section{Body chemical composition:}

Table (6) showed the Chemical composition (\%) of tilapia fillets and bioflocs formed during the 60 days of rearing (O. niloticus) culture in water-reusing biofloc. The proximate composition of fish whole body may change as a reflection of a number of factors, including water quality, stress factors, availability of nutrients, feed intake and utilization (Dawood et al., 2016). In the present study, the whole-body fat recorded the highest value in $T 2$ and the lowest value recorded in $\mathrm{T} 1$ and $\mathrm{T} 3$. The decrease in ether extract (EE) can be attributed to the decreased feed intake that can result in low amounts of accumulated lipids in body composition. The highest protein content was recorded in $\mathrm{T} 1$ followed by $\mathrm{T} 3$ and $\mathrm{T} 2$, respectively. The results of the present study were close to the data found by (Verma et al., 2016). In contrast with our result, (Azim and Little, 2008) recognized no significant difference between clear and biofloc 6 in chemical composition of Nile tilapia. Ash in biofloc system had the highest content it might be explained by continuous availability of abundant minerals and trace elements from the bioflocs. The results of the present study were close to the data found by (Eid et al., 2020).

Table (6): Chemical composition of Nile tilapia fingerlings.

\begin{tabular}{lccc}
\hline Item & T1 (CO.) & T2 $(\mathrm{Bf}+\mathrm{c})$ & T3 $(\mathrm{Bf}-\mathrm{c})$ \\
\hline Dry mater & $25.44 \pm 0.20 \mathrm{a}$ & $24.46 \pm 0.24 \mathrm{~b}$ & $23.80 \pm 0.28 \mathrm{c}$ \\
Protein \% & $60.67 \pm 0.27 \mathrm{a}$ & $58.84 \pm 0.27 \mathrm{~b}$ & $59.36 \pm 0.24 \mathrm{~b}$ \\
EE \% & $19.05 \pm 0.27 \mathrm{~b}$ & $20.90 \pm 0.20 \mathrm{a}$ & $19.99 \pm 0.26 \mathrm{~b}$ \\
Ash \% & $17.36 \pm 0.27 \mathrm{~b}$ & $18.37 \pm 0.22 \mathrm{a}$ & $18.16 \pm 0.28 \mathrm{a}$
\end{tabular}

Data presented as means \pm standard error (SE). Values in the same row with different superscript letters are significantly different $(p<0.05)$..

\section{Economic Evaluation:}

Calculations of economic efficiency of the tested diets based on the cost of feed, costs of one $\mathrm{Kg}$ gain in weight and its ratio with the control group are shown in Table 7 . The lowest feed cost per $\mathrm{kg}$ fresh fish was in T2 (0.79 LE), Relative \% of feed cost $/ \mathrm{kg}$ fish $(83.58 \%)$, Feed cost $/ 1 \mathrm{Kg}$ gain T2 (11.59 LE) and Relative \% of feed cost of Kg gain $(70.93 \%)$ in group of fish fed diet $\mathrm{T} 2$.

Table (7): Economic analysis of Nile tilapia fingerlings reared under different water system for 60 day.

\begin{tabular}{lccc}
\hline & \multicolumn{3}{c}{ Treatment } \\
\cline { 2 - 4 } Item & $\begin{array}{c}\mathrm{T} 1 \\
\text { (control })\end{array}$ & $\begin{array}{c}\mathrm{T} 2 \\
(\mathrm{Bf}+\mathrm{c})\end{array}$ & $\begin{array}{c}\mathrm{T} 3 \\
(\mathrm{Bf}-\mathrm{c})\end{array}$ \\
\hline Cost /kg diet (LE) & 7.20 & 7.20 & 7.20 \\
Consumed feed to produce 1 kg fish (kg) & 2.27 & 1.61 & 1.73 \\
Feed cost per kg fresh fish (LE) & 0.95 & 0.79 & 0.82 \\
Relative \% of feed cost/ kg fish & 100 & 83.58 & 86.31 \\
Feed cost /1 Kg gain (LE) & 16.34 & 11.59 & 12.46 \\
Relative \% of feed cost of Kg gain & 100 & 70.93 & 76.25 \\
\hline
\end{tabular}




\section{CONCLUSION}

It could be concluded that the best growth performance, feed utilization, survival, productive performance, proximal composition and economic evaluations for Nile tilapia fingerlings can be achieved by rearing fish in reusing water from systems with biofloc technology (BFT) without adding carbon source, which prolonged the useful life and quality of water and reduced overall water consumption. So it could be considered as an additional strategy to maintain or increase production of Nile tilapia.

\section{REFERENCES}

Ahmad, H. I., A. K.Verma, A.M. Babitha Rani, G. Rathore, N. Saharan and A. H. Gora (2016) Growth, non-specific immunity and disease resistance of Labeorohita against Aeromonashydrophila in biofloc systems using different carbon sources. Aquaculture, 457:61-67.

Amin, A., A. El Asely, A. S. Abd El-Naby, F. Samir, A. El-Ashram, R. Sudhakaran, and M. A. Dawood (2019). Growth performance, intestinal histomorphology and growth-related gene expression in response to dietary Ziziphusmauritiana in Nile tilapia (Oreochromis niloticus). Aquaculture, 512, 734301.

AOAC (1995). Association of Official Analytical Chemists. Official Methods of Analysis, 15th ed., Arlington, VA.

APHA (1992). Standard Methods for the Examination of Water and Wastewater, 18th ed. American Public Health Association, Washington DC. 1268.

Avnimelech, Y. (1999). Carbon/nitrogen ratio as a control element in aquaculture systems. Aquaculture, $176: 227-235$

Avnimelech, Y. (2009). Biofloc technology - a practical guide book, 1st edition. The World Aquaculture Society, Baton Rouge, Louisiana, USA.

Avnimelech, Y. (2011, April). Tilapia production using biofloc technology (BFT). In Proc 9th Int Symp on Tilapia in Aquaculture (pp. 362-366).

Avnimelech, Y. (2012). Biofloc Technology. A Practical Guide Book. Louisiana (US). World Aquaculture Society.

Avnimelech, Y. and M. Kochba (2009). Evaluation of nitrogen uptake and excretion by tilapia in biofloc tanks, using $15 \mathrm{~N}$ tracking. Aquaculture, 287(1-2):163-168.

Azim, M.E., and D.C. Little (2008). The biofloc technology (BFT) in indoor tanks: water quality, biofloc composition and growth and welfare of Nile tilapia, Oreochromis niloticus. Aquaculture, 283:29-35.

Bakhshi, F., E.H. Najdegerami, R. Manaffar, A. Tukmechi and K.R. Farah (2018). Use of different carbon sources for the biofloc system during the grow-out culture of common carp (Cyprinuscarpio L.) fingerlings. Aquaculture, 484:259-267.

Barak, Y., E. Cytryn, I. Gelfand, M. Krom \& J. van Rijn (2003). Phosphorus removal in a marine prototype, recirculating aquaculture system. Aquaculture, 220: 313-326 .

Caipang, C. M., H. X. Choo, Z. Bai, H. Huang, C. M. Lay-Yag and J. Lim (2015). Small-scale production of biofloc using various carbon sources for the freshwater culture of tilapia, Oreochromis sp. Animal Biology \& Animal Husbandry, 7(1): 103-

Crab, R. (2010). Bioflocs technology: an integrated system for the removal of nutrients and simultaneous production of feed in aquaculture. PhD Thesis, Ghent University. Pp. 178.

Crab, R., Y. Avnimelech, T. Defoirdt, P. Bossier and W. Verstraete (2007). Nitrogen removal techniques in aquaculture for a sustainable production. Aquaculture, 270(1-4): 1-14. 


\section{Eid et al.}

Dauda, A.B., N. Romanol, M. Ebrahimi, J.C. A. The, A. jadi, L. Chong, M. Karim, I. Natrah and M, S. Kamarudin (2018). Influence of carbon/nitrogen ratios on biofloc production and biochemical composition and subsequent effects on the growth, physiological status and disease resistance of African catfish (Clariasgariepinus) cultured in glycerol-based biofloc systems. Aquaculture, 483:120130.

Dawood, M. A., N. M. Eweedah, Z. I. Elbialy, and A. I. Abdelhamidl (2020). Dietary sodium butyrate ameliorated the blood stress biomarkers, heat shock proteins, and immune response of Nile tilapia (Oreochromis niloticus) exposed to heat stress. Journal of Thermal Biology, 88: 102500.

Dawood, M. A., M. Zommara, N. M. Eweedah and A. I. Helal (2019). Synergistic effects of selenium nanoparticles and vitamin $\mathrm{E}$ on growth, immune-related gene expression, and regulation of antioxidant status of Nile tilapia (Oreochromis niloticus). Biological trace element research, 1-12.

Dawood, M.A., Shunsuk, Koshio, S, Yokoyama, S. (2016). Effects of heat killed Lactobacillus plantarum (LP20) supplemental diets on growth performance, stress resistance and immune response of red sea bream, Pagrus major Aquaculture, 442(1):29-36.

De Schryver, P., R. Crab, T. Defoirdt, N. Boon and W. Verstraete (2008). The basics of bio-flocs technology: the added value for aquaculture. Aquaculture, 277(3-4): 125-137.

Duncan, D. B. (1995). Multiple rang and multiple F test. Biomertics, 11(1)

Eid, A., K. Elsayed, M. M. Said, E. M. Taha, B. A. Aali, H. E. Eissa and Y. Khattab (2020). Effects of Stocking Density on Growth Performance and Utilization of Nile Tilapia Fingerlings Under Biofloc System, AbbassaInt J., 13. (2): 233-356.

Ekasari, J., M.A. Suprayudi , W.Wiyoto1 , R. F. Hazanah , G.S. Lenggara , R. Sulistiani, M . AlkahfiM and M . Zairin (2016). Biofloc technology application in African catfish fingerling production: the effects on the reproductive performance of brood stock and the quality of eggs and larvae. Aquaculture, 464:349-356

Ekasari, J., M.J. R. Zairin , D. U. Putri, N. P. Sari, E.H. Surawidjajaand and P. Bossier (2013) .Bioflocbased reproductive performance of Nile tilapia Oreochromis niloticus L. brood stock. Aquaculture Research 46:509-512.9

Elías, J.A, A.M. Arias, A.M. Baeza, L.R. Martínez-Córdov, M.E. Rivas-Vega and E.A. Márquez-Ríos (2015) Proximate Composition of Bioflocs in Culture Systems Containing Hybrid Red Tilapia Fed Diets with Varying Levels of Vegetable Meal Inclusion, North American Journal of Aquaculture, $77: 1$.

FAO (2018). The State of World Fisheries and Aquaculture. Meeting the sustainable development goals. Food and Agriculture Organization, Rome.

García-Ríos, L., A. Miranda-Baeza, M. G.Coelho-Emerenciano, J. A. HHuerta-Rábago and P. uertaRábagoaOsuna-Amarillas (2019). Biofloc technology (BFT) applied to tilapia fingerlings production using different carbon sources: Emphasis on commercial applications. Aquaculture, 502: 26-31.

Hari, B., Kurup, B.M., Varghese, J.T., Schrama, J.W. and Verdegem, M.C.J. (2006). The effect of carbohydrate addition on water quality and the nitrogen budget in extensive shrimp culture systems. Aquaculture, 252 (2-4): 248-263.

Khanjani, M. H., M. M. Sajjadi, M. Alizadeh and I. Sourinejad (2017). Nursery performance of Pacific white shrimp (Litopenaeusvannamei Boone, 1931) cultivated in a biofloc system: the effect of adding different carbon sources. Aquaculture Research, 48(4): 1491-1501.

Krummenauer, D., S. Peixoto, R. O. Cavalli, L. H. Poersch, and W. Wasielesky. (2011). Super intensive culture of white shrimp, Litopenaeusvannamei, in a biofloc technology system in southern Brazil at different stocking densities. Journal of the World Aquaculture Society, 42:726-733.

Krummenauer, D., T. Samocha, L. Poersch, G.Lara and W.J.r. Wasielesky (2014). The reuse of water on the culture of pacific white shrimp Litopenaeusva.nnamei, in BFT system. J World. Aquaculture Society, 45:3-14.

Kubitza, F. (2011). Tilapia: technologies e planejamentoan produçãocomercial. Acqua Supre Com. Suprim. Aquaculture Ltda. Jundiai. 
Long, L., J. Yang, Y. Li, C. Guan and F. Wu (2015). Effect of biofloc technology on growth, digestive enzyme activity, hematology, and immune response of genetically improved farmed tilapia (Oreochromis niloticus). Aquaculture, 448: 135-141.

Luo, G., Q. Gao, C. Wang, W. Liu, D. Sun, L. Li and H. Tan (2014). Growth, digestive activity, welfare, and partial cost-effectiveness of genetically improved farmed tilapia (Oreochromis niloticus) cultured in a recirculating aquaculture system and an indoor biofloc system. Aquaculture, 422: 1-7.

Magouz, F. I., M. A. Dawood, M. F. Salem and A. A. Mohamed (2020). The effects of fish feed supplemented with Azolla meal on the growth performance, digestive enzyme activity, and health condition of geneticallyimproved farmed tilapia (Oreochromis niloticus). Annals of Animal Science, 1(ahead-of-print).

Mirzakhani, N., E. Ebrahimi, S. A. H. Jalalil and J. Ekasari (2019) Growth performance, intestinal morphology and nonspecific immunity response of Nile tilapia (Oreochromis niloticus) fry cultured in biofloc systems with different carbon sources and input C: N ratios. Aquaculture, 512: 734235

Mullin, J. B. and J. P. Rileyl (1955). The colorimetric determination of silicate with reference to sea and natural aters. Ana 1.Chim .Acta, 12: 162-176.

Najdegerami E. H., F. Bakhshi and F. B. Lakani (2016) Effects of biofloc on growth performance, digestive enzyme activities and liver histology of common carp (Cyprinuscarpio L.) fingerlings in zero-water exchange system. Fish Physiology and Biochemistry, 42: 457- 465.

Nootong, K. and P. Pavasant (2011). Effects of organic carbon addition in controlling inorganic nitrogen concentrations in a biofloc system. Journal of the World Aquaculture Society, 42: 339-346.

NRC (2011). National Research Council. Nutrient Requirement of Fish, National Academic Prees, washington, DC, USA.

Panigrahi, A., M. Sundaram, C. Saranya, R. Satish Kumar, J. SyamaDayal and R. Saraswath (2019) Influence of differential protein levels of feed on production performance and immune response of pacific white leg.

Pérez-Fuentes, J. A., M. P. Hernández-Vergara, C. I. Pérez-Rostro, and I. Fogel (2016). C: N ratios affect nitrogen removal and production of Nile tilapia Oreochromis niloticus raised in a biofloc system under high density cultivation. Aquaculture, 452: 247-251.

SAS (2004). Statistical Analysis System Institute. User's Guide: statistics. SAS Institute Inc., Cary .

Van Doan, H., S. H. Hoseinifar, K. Sringarm, S. Jaturasitha, B. Yuangsoi, M. A. Dawoodl, and C. Faggio (2019). Effects of Assam tea extract on growth, skin mucus, serum immunity and disease resistance of Nile tilapia (Oreochromis niloticus) against Streptococcus agalactiae. Fish \& shellfish immunology, 93: 428-435.

Verma, A. K., A. B. Rani, G. Rathore, N. Saharan and A. H. Gora (2016). Growth, non-specific immunity and disease resistance of Labeorohita against Aeromonashydrophila in Biofloc systems using different carbon sources. Aquaculture, 457: 61-67.

Wang, G., E. Yu, J. Xie, D. Yu, Z. Li, W. Luo, L. Qiu and Z. Zheng (2015). Effect of C/N ratio on water quality in zero-water exchange tanks and the biofloc supplementation in feed on the growth performance of crucian carp, Carassiusauratus. Aquaculture 443:98-104.

Xu, W. J., T. C. Morris and T. M. Samocha (2016a). Effects of C/N ratio on biofloc development, water quality, and performance of Litopenaeus vannamei juveniles in a biofloc-based, high-density, zeroexchange, outdoor tank system. Aquaculture, 453: 169-175.

Xu, Z., E. Li, C. Xul, L. Gan, J. G. Qin and L. Chen (2016b). Response of AMP-activated protein kinase and energy metabolism to acute nitrite exposure in the Nile tilapia Oreochromis niloticus. Aquatic Toxicology, 177: 86-97.

Yanbo, W., Z. Wenju, L. Weifen and X. Zirong (2006). Acute toxicity of nitrite on tilapia ( niloticus) at different external chloride concentrations. Fish Physiology.

Zhao, D., L. Pan, F. Huang, C.Wang and W. Xu (2016). Effects of different carbon sources on bioactive compound production of biofloc, immune response, antioxidant level, and growth performance of Litopenaeusvannamei in zero-water exchange culture tanks. Journal of the World Aquaculture Society, 47: 566- 576. 
Eid et al.

تأثير إعادة استخدام مياه البيوفلوك على أداء النمو والاستفادة من الغذاء لإصبعيات البلطي النيلي

عبد الحميد صلاح عيد ، خلود جلال شهدي ، مرفت على محمد و أمال الفقى

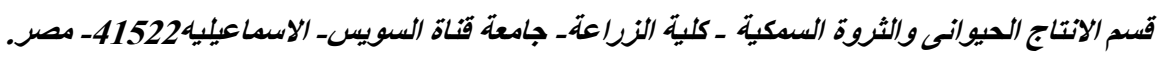

تم إجر اء هذه التجربة لدر اسة تأثير إعادة استخدام مياه البيوفلوك على أداء النمو والاستفادة من الغذاء و التأ التركيب الكميائي لجسم

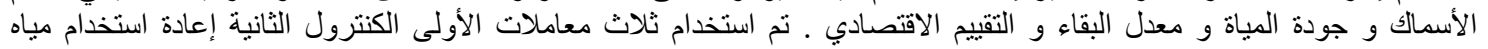

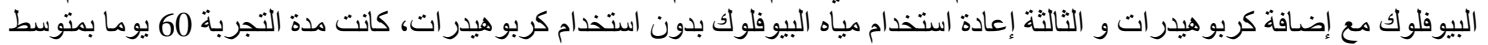

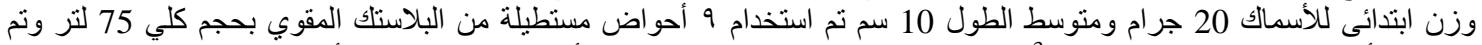

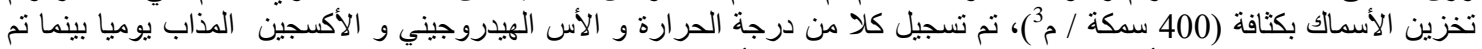

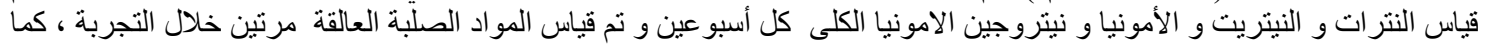

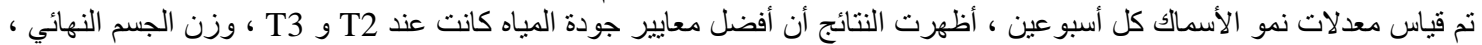

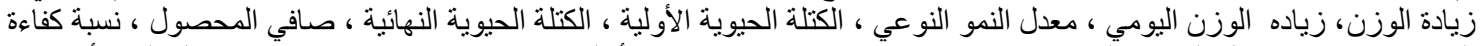

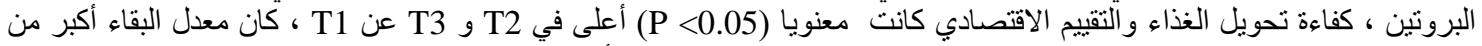

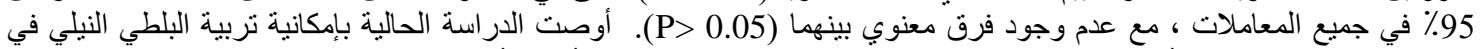

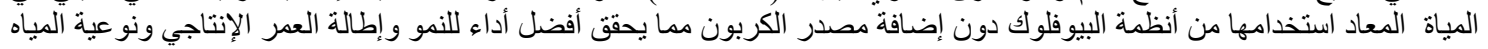
وتقليل الاستهلاك الكلي للمياة. 